\title{
An Examination of Social Capital in Young People According to Life Satisfaction and Some Socio-Demographic Factors
}

\author{
DOI: 10.26466/opus.904662
}

\author{
M. Serhat Öztürk * - Nihan Yılmaz** \\ * Assoc. Prof. Dr., Hacettepe University, Ankara/ Turkey \\ E-Mail: \\ sozturk@hacettepe.edu.tr \\ ORCID: $0000-0002-7285-983 X$ \\ ** Dr., Hacettepe University, Ankara/ Turkey \\ E-Mail: \\ nihangursoy@hacettepe.edu.tr \\ ORCID: $0000-0002-2451-0852$
}

\begin{abstract}
The premise behind social capital is relatively simple and straightforward: investment in social relations with expected returns. Individuals build relationships and form networks in order to obtain certain returns: physical health, mental health, and life satisfaction. Strong bonds between people with similar characteristics and attitudes will help increase the frequency of interaction and the life satisfaction of an individual. Accordingly, when the relevant literature on this crucial issue was examined, it was found that there are a limited number of studies evaluating the relationship between the social capital and life satisfaction of young people in Turkey. Given the lack of literature, it is essential to determine the relationship between social capital and life satisfaction. This study was aimed and conducted to evaluate the relationship between social capital and life satisfaction between young people. The study data were collected from face-to-face interviews with 500 young people between the ages of 18-29 who were selected using the "convenience sampling method". In this study "Social Capital Scale" and "Satisfaction with Life Scale" was used. Social capital and life satisfaction score mean of the participants is well above the medium level. Social capital level and life satisfaction were found to be positively correlated.
\end{abstract}

Keywors: Social Capital, Life Satisfaction, Young People. 


\section{Gençlerde Sosyal Sermayenin, Yaşam Tatmini ve Bazı Sosyo-Demografik Faktörlere Göre İncelenmesi}

\section{Öz}

Sosyal sermayenin altında yatan temel varsayım, sosyal ilişkilere yatırım yapıldığı sürece arzulanan amaçlara ulaşılacağı yönündedir. Bireylerin ilişkiler kurması, ă̆lar oluşturması birtakım getiriler elde etmek amacıyla yapılır: fiziksel sağllk, zihinsel sağllk ve yaşam tatmini. Benzer özelliklere ve tutumlara sahip kişiler arasında kurulan güçlü bağlar, etkileşim sıklı̆̆ını arttırarak, bireyin yaşam tatminini arttırmada faydah olacaktır. İlgili literatür incelendiğinde, ülkemizde gençlerin sosyal sermaye ile yaşam tatmini arasındaki ilişkiyi inceleyen çalışmalar sınırlı sayıdadır ve literatürdeki eksiklik göz önüne alındığında sosyal sermaye ile yaşam tatmini arasındaki ilişkinin belirlenmesi önem taşımaktadır. Bu çalışma, gençlerde sosyal sermaye ve yaşam tatmini arasındaki ilişkinin incelenmesi amacıyla planlanmış ve yürütülmüş̧ür. Çalışmanın verileri, "kolay ulaşılabilir örnekleme yöntemi" ile seçilen 1829 yaş arası 500 genç ile yüz yüze yapılan görüşmeler sonucu toplanmıştır. Araştırmada, "Sosyal Sermaye Ölçeği" ve "Yaşam Tatmini Ölçeği" kullanılmıştır. Araştırmaya katılanların sosyal sermaye puan ortalaması ve yaşamdan duyulan tatmin puan ortalamasının orta düzeyin üstünde olduğu görülmektedir. Sosyal sermaye düzeyi ile yaşamdan duyulan tatmin arasında pozitif yönlü ilişkili bulunmuştur.

Anahtar Kelimeler: Sosyal Sermaye, Yaşam Tatmini, Genç. 


\section{Introduction}

Throughout the historical development process of the social capital concept, indirect definitions have been made in social sciences, especially in the fields of economic thought, sociology and psychology, and with the sociological approaches of important scholars such as Durkheim, Marx, Weber; the concept has been tried to be explained in connection with the Social Change and Psychological Contract theories, in which the social relations of the individual are examined (Watson and Papamarcos, 2012). Adam Smith, who first studied this relationship with a long history of etymology, drew attention to the close ties between economic and social sciences in his book "Wealth of Nations" (1776). Examining the relationship between education and economic growth, Smith stated that expenses should exist for the education people receive and that the savings gained as a result of these expenses are a capital accumulation, from which all segments of the society will benefit (cited in Khan, Hussain, Shahbaz, Yang and Jiao, 2020).

Conceptually, first use of 'social capital' has a long history; nonetheless, it took a long time for this concept to reach the understanding and usage patterns it expresses today. There are quite a few scholars that made a distinguished name regarding the social capital. Nevertheless, as can be seen from the abstracts of these studies, the researches, evaluations and the studies presented were conducted based on Pierre Bourdieu, James Coleman, Robert Putnam and Francis Fukuyama. Studies of Pierre Bourdieu takes the first place in this regard (Aydemir, 2011). Bourdieu acknowledges that social capital includes all natural and potential resources associated with a constantly functioning network (1986, p.248). Bourdieu (1977, p.503) defines social capital as follows: "Capital of social relationships will provide, if necessary, useful support". Bourdieu (1986) also emphasizes that individuals must work in order for social capital to maintain its value. The reconstruction of social capital requires constant socialization. Time and energy are deemed necessary.

On the other side, Coleman considers social capital not as individual, but as relationships between individuals. Coleman remarked that social capital can take different forms. Trust, norms and sanctions within a group are essential in understanding social capital. Coleman's concept of 
social capital differs from Bourdieu's perception. This difference indicated that this capital concept applies to the powerful and the rich and provides significant benefits to the poor and marginalized communities. However, both Bourdieu and Coleman share a common understanding of social capital as a source of educational success. For Coleman, social capital represents a resource. Because social capital includes expectations for reciprocity. This reciprocity in social relations enables wider communication networks.

Considering the main idea of the theory of social capital set forth by Putnam (2000, p.18-19), the most cited author with his studies on social capital who gained popularity in the academic world, social communication networks have value. Social ties affect the productivity of individuals and groups and empower them in a context.

As for Francis Fukuyama (1998, p.36-37), who studied the theory of social capital in the field of economics, civil society and social values, the acquisition of social capital enables the moral norms of a community to become a pattern, the acquisition of virtues such as loyalty and honesty, and the interdependence of individuals. According to Fukuyama, conveyance should be in line with the moral value prevalent in the society. Through social capital, people can socialize, receive and transfer the values encoded in the society.

Social capital includes all the intangible assets in the society. The wide scope of the concept brings along uncertainties regarding its definition (Özuğurlu, 2006, p.190). Social capital can be briefly understood in the following two-word sentence formulated by John Field (2006, p.1): Relationships matter. Inherently, humans establish associations and networks, they exist in these networks to maintain their lives easier and more sustainable. The communication networks that emerge from this union perform a vital task for creating and transmitting common values (Field, 2006, p.4). Field states that the more people you know and the more common sense of life you share with them, the richer you are in social capital. People who can get help from others are healthier, happier and wealthier than those who cannot. All these capital approaches meet on a common ground; capital should be evaluated as a power (Nitzan-Bichler, 2009), even though it remains implicit. Capital is a force for its owner and for the context in which it is set forth. 
The aspect of the operational definition shown in the table should not be considered to be the only aspect to which the dimension relates, each dimension may relate to other aspects in different contexts. It has been developed by identifying what appear to be the main dimensions for the measurement of social capital and then considering what aspects of those dimensions we should be looking to measure.

\begin{tabular}{|c|c|}
\hline Social Capital Dimensions & Definitions \\
\hline Social participation (networks) & $\begin{array}{l}\text { - Number of cultural, leisure, social groups belonged to } \\
\text { - Frequency and intensity of involvement } \\
\text { - Involvement with voluntary organisations } \\
\text { - Frequency and intensity of involvement } \\
\text { - Religious activity }\end{array}$ \\
\hline $\begin{array}{l}\text { Social networks and social support } \\
\text { (networks) }\end{array}$ & $\begin{array}{l}\text { - Frequency of seeing and speaking to relatives, friends or } \\
\text { neighbours } \\
\text { - virtual networks - frequency and intensity of contact } \\
\text { - how many close friends or relatives live nearby } \\
\text { - who can be relied on to provide help } \\
\text { - who provide help to } \\
\text { - perceived control over life } \\
\text { - satisfaction with life }\end{array}$ \\
\hline $\begin{array}{l}\text { Reciprocity and trust (shared norms and val- } \\
\text { ues) }\end{array}$ & $\begin{array}{l}\text { - trust in other people who are like you } \\
\text { - trust in other people who are not like you } \\
\text { - people will do favours and vice versa } \\
\text { - perception of shared values }\end{array}$ \\
\hline Civic participation (co-operation) & $\begin{array}{l}\text { - confidence in institutions at different levels } \\
\text { - perceptions of ability to influence events } \\
\text { - how well informed about local or national affairs } \\
\text { - contact with public officials or political representatives; } \\
\text {-involvement with local action groups; frequency } \\
\text { - propensity to vote }\end{array}$ \\
\hline $\begin{array}{l}\text { Views of the local area (shared norms and va } \\
\text { ues) }\end{array}$ & $\begin{array}{l}\text { - views of physical environment } \\
\text {-- facilities in the area } \\
\text { - enjoyment of living in the area } \\
\text { - fear of crime }\end{array}$ \\
\hline
\end{tabular}

Ref.: Harper, R. (2002). The measurement of social capital in the United Kingdom. Office for National Statistics, 11, 2019.

The organization for Economic Cooperation and Development (OECD) and the World Bank conduct serious research on social capital worldwide and develop international policies. In these studies, the OECD measures social capital at five basic levels. These are; (1) Social participation; taking part in groups and voluntary organizations, (ii) Social networks and support; Establishing relationships with friends and relatives. (iii) Reciprocity 
and trust; giving and receiving gifts, doing favors and other behaviours like these, trusting other people and institutions such as the police and the government; (iv) Civic participation; voting rates, taking action on local or national issues; (v) Views of the local area (shared norms and values); thoughts about the social environment (neighborhood). Although it is not closely related to the evaluation of social capital, perceptions such as the level of satisfaction and problems related to the inhabited area are necessary in the analysis and interpretation for the evaluation of social capital (Harper, 2002, p.5). In the Social Capital Workshop organized by the World Bank in 1999, economist Kenneth Arrow discussed the abandonment of social capital. Arrow (2000) perceived the capital as willingly making sacrifices today for future benefits. Notwithstanding, social networks created for reasons other than economic value do not comply with this characteristic of capital as they do not require any sacrifice. Woolcock (2000) responded such objections as follows: "Many people inherit social capital, meaning they have little influence to own the social capital. Regardless, in many cases, people plan and consciously make efforts to increase their social capital, which indicates that social capital has a certain cost." On the other hand, like other forms of capital, social capital is not costless to produce and requires a significant amount of time and effort (Chou, 2003).

The premise behind social capital is relatively simple and straightforward: investment in social relations with expected returns. (Lin, 1999). This capital accumulation can benefit people in the field where it occurs and benefit people in many different fields of their life. Therefore, the more people an individual knows and if new values are created and a common view is shared in relationships with people, the richer he/she is in terms of social capital (Field, 2006). Individuals build relationships and form networks in order to obtain certain returns. Expressive returns, another benefit of social capital, help consolidate resources and prevent possible resource losses. The rule is to contact those who control similar resources and share similar interests. In this way, existing resources are preserved and maintained. Three types of return may be specified: physical health, mental health, and life satisfaction (Lin, 1999). The bonds and satisfaction levels of the relationships within the group improve and deter- 
mine the individual's well-being and psychological health (Leary, Tambor, Terdal and Downs, 1995). Strong bonds between people with similar characteristics and attitudes will help increase the frequency of interaction and the life satisfaction of an individual (Lin, 1999). Social Capital is the sum of the relationships an individual establishes with his/her environment. On the other hand, life satisfaction is the reflection of the results of such relationships on the entire life (Ardahan, 2014a).

Throughout their lives, people go through interconnected periods such as childhood, youth, adulthood and elderliness, supervening one another. Youth period is the most effective and productive of all these periods $(\mathrm{Mu}-$ rat and Şahin, 2011a, p.96). Social capital is crucial for individuals of all age groups. Considering the characteristics of young people who are considered the future of society, it was preferred to approach social capital independently from other age groups.

Life satisfaction is one of the most important factors that should be examined to understand young people's problems. Life satisfaction is a concept that includes all aspects of an individual's life, with self-criticism of the person as per his/her criteria about life expectations, desires and how much of his goals he/she can achieve as well as expressing the state of well-being in different aspects such as morale and happiness (Bulut, 2016; Tel and Sar1, 2016). The sense of satisfaction an individual receives from his/her life, plans, the desire to change one's life, that is, all the thoughts an individual has about his/her life constitutes the life satisfaction (Diener, Suh, Lucas and Smith, 1999).

The youth period is one of the most critical processes in which the perpetual behaviors of an individual is shaped, and the seeds of the satisfaction an individual will receive from life throughout his/her life are sown in this period. Accordingly, when the relevant literature on this crucial issue was examined, it was found that there are a limited number of studies evaluating the relationship between the social capital and life satisfaction of young people in Turkey. In his research evaluating the relationship between social capital and life satisfaction from university students, Ardahan (2014a) found a linear relationship between social capital perception and life satisfaction. The students' life satisfaction is at a moderate level and there is a successive increase in social capital and life satisfaction on a mutual basis. A similar study conducted by Uçar and Morsünbül 
(2018) on university students concluded that social capital is low between young people.

The findings obtained in the study conducted by Keleş, Keskin and Ertek (2018) on rural and village residents; including individuals in the young age group, indicate a strong relationship between social capital and life satisfaction. Research results revealed that both three types of social capital has a positive impact on life satisfaction. The relevant study is of great importance, considering that young people's opportunities in rural areas to improve their social capital are more limited.

In most of the studies conducted abroad on social capital, a positive relationship was found between social capital and life satisfaction (McPherson, Kerr, McGee, Morgan, Cheater, McLean and Egan, 2014; Bjørnskov, 2008; Klein, 2013). When examining the studies conducted upon evaluating the relationship between social capital and life satisfaction from the point of young people, James Coleman (1988) stated that social capital leads to satisfaction by affecting young people's educational attainment. The study conducted by Alghamdi and Plunkett (2021) suggests that students' social capital has a substantial impact on life satisfaction particulary. In the study conducted by Geraee, Eslami and Soltani (2019) aiming to investigate the relationships between social capital, social media use and life satisfaction and to determine the effect of social media use on the relationship between social capital and life satisfaction in young people, it was found that social capital is the most vital precursor of life satisfaction.

\section{Objectives and Questions}

The main purpose of this study is to determine to what extent the relations between individuals, institutions and organizations contribute to the achievement of the general goals of the society with economic and social content. Also given the lack of literature, it is essential to determine the relationship between social capital and life satisfaction. This study was aimed and conducted to evaluate the relationship between social capital and life satisfaction between young people. With this, it is thought that this study will contribute to the literature by evaluating the relationship 
between life satisfaction and social capital, which is one of the critical indicators in terms of increasing social welfare.

In this regard, answers were sought regarding the following research questions:

1. Is there a relationship between the level of social capital and life satisfaction between young people?

2. Does social capital differ according to age, gender, education level, parental education level, employment status and perceived income level?

\section{Methodology}

\section{Study Group}

No sample selection was made in this descriptive study. The study data were collected from face-to-face interviews with 500 young people between the ages of 18-29 who were selected using the "convenience sampling method" from Bahçelievler, Emek and Beşevler districts of Ankara Çankaya between July 1-15, 2020. "Convenience sampling method is a sampling method performed on (volunteer) individuals who are present in the immediate vicinity and are easy to come by, available and who are willing to participate in the study" (Erkuş, 2013). In the first page of the research form, preliminary information was provided to the participants about the study's objective, the importance of participation in the study, the confidentiality of the answers given, participation being on an entirely voluntary basis and the contact with the researcher. Each interview lasted approximately 8 minutes.

\section{Data Collection Tool}

Before the implementation phase of the research form, official permissions were obtained from the relevant service unit of the Ankara Governorship. In the first page of the research form, preliminary information was provided to the participants about the study's objective, the importance of 
participation in the study, the confidentiality of the answers given, participation being on an entirely voluntary basis, and the contact with the researcher.

The questionnaire consists of three parts.

In the first part, there are socio-demographic questions such as gender, age, education level, parental education status, working status, perceived income level, including the demographic information of the young people participating in the survey.

In the second part, "Social Capital Scale" developed by Onyx and Bullen (2000) and adapted by Ardahan (2012), was used to determine the social capital levels of the participants. In this study, Cronbach's Alpha coefficient of the scale was reported as 0.82 . The 4-point Likert scale was used to evaluate the scale items, and the options were weighted as "1Strongly Disagree, 2- Disagree, 3- Agree, 4-Strongly Agree".

The "Satisfaction with Life Scale (SWLS)", developed by Diener, Emmons, Larsen and Griffin (1985), was used to measure the life satisfaction of young people. The scale consists of 5 likert-style items. In this study, each item was scored between 1 (strongly disagree) and 5 (strongly agree). The scores obtained from the scale are between 5 and 25, and the high scores indicate that the individuals' satisfaction with life is also high. Diener et al. (1985) found the internal consistency of the Satisfaction with Life Scale as $\alpha=0.87$. The scale was adapted to Turkish by Köker (1991), and its internal consistency was found to be $\alpha=0.80$. In this study, the Life Satisfaction Scale internal consistency coefficient (Cronbach's Alpha) was calculated $(\alpha=0.87)$ and was found to be reliable.

\section{Analysis of the Data}

SPSS 24.0 package program was used for statistical analysis of the data obtained from the study. The participants' demographic and descriptive information were expressed with descriptive statistics such as number, percentage, mean and standard deviation. Mean and standard deviation values for the social capital and life satisfaction of young people were found. "Student's t-test" and "Analysis of Variance" were used to determine whether social capital was differentiated as per various socio-demographic factors. "Student's t-test" was used in cases where there are two 
groups (such as; gender), and "Analysis of Variance" was used in cases where there are more than two groups (such as; educational status, monthly income, age) in order to determine whether there is a difference between variables in the study. "Multiple Comparison Test" (Tukey's) was used to examine from which group or groups the difference originated in the wake of the analysis, and the results were given in tables. Bidirectional Pearson Correlation Analysis was used to determine the direction and strength of bilateral relations between social capital and life satisfaction.

\section{Ethical Principles}

Signed and informed consent was obtained from all participants in the study. Approval to conduct this study was granted by the Ethical Committee of Hacettepe University Board on June 23, 2020, (no: 35853172-200) by the Declaration of Helsinki.

\section{Results}

In the analysis of Table 1, it was found that $55 \%$ of the participants were female, and $45 \%$ of them were male; and of the participants, $33.8 \%$ were between the ages of $18-22,42.8 \%$ were between $22-25$, and $23.4 \%$ were between $26-29$. It was also determined that $74.2 \%$ of the participants' educational status was 'undergraduate', and $9.4 \%$ were 'masters/doctorate'. Considering the parental educational status, it was determined that $63.2 \%$ were at "high school level and below", 29.8\% were "undergraduate", and $7 \%$ were "graduate". The participants' employment status was examined, and it was determined that $57.2 \%$ of the participants are 'unemployed', $16 \%$ ' work part-time, and $26.8 \%$ ' work full time. Participants were asked about the convenience of their income status, and $11.2 \%$ of them answered 'low', 77.2\% answered "medium", and 11.6\% answered, "high". 
Table 1. General Findings

\begin{tabular}{lll}
\hline & $\mathbf{N}$ & $\%$ \\
\hline Age Groups & 240 & 48.0 \\
$\mathbf{1 8 - 2 2}$ & 260 & 52.0 \\
$\mathbf{2 3 - 2 9}$ & & \\
\hline Gender & 225 & 45 \\
Male & 275 & 55 \\
Female & & \\
Educational Status & 82 & 16.4 \\
High school and below & 371 & 74.2 \\
Undergraduate & 47 & 9.4 \\
Postgraduate & & \\
Parental Educational Status & 316 & 63.2 \\
High school and below & 149 & 29.8 \\
Undergraduate & 35 & 7.0 \\
Postgraduate & & \\
Employment Status & 286 & 57.2 \\
Unemployed & 80 & 16.0 \\
Part Time & 134 & 26.8 \\
Full Time & & \\
Perceived Income Status & 56 & 11.2 \\
Low & 386 & 77.2 \\
Medium & 58 & 11.6 \\
High & $\mathbf{5 0 0}$ & $\mathbf{1 0 0 . 0}$ \\
Total & & \\
\hline & & \\
\hline & & \\
\hline
\end{tabular}

It can be seen that the social capital score mean of the participants $(74.63 \pm 9.05)$ is well above the medium level. The life satisfaction score mean $(15,42 \pm 4,35)$ of the participants is also above the medium level (Table 2).

Table 2. Descriptive Statistics of Social Capital and Life Satisfaction

\begin{tabular}{lllll}
\hline & N & Min-Max & Avg. & Std. Deviation \\
\hline Social Capital & 500 & $49-105$ & 74.63 & 9.05 \\
Life Satisfaction & 500 & $5-25$ & 15.42 & 4.35 \\
\hline
\end{tabular}

T-test and ANOVA results are present in table 3, comparing the score mea of social capital and life satisfaction in accordance with socio-demographic variables. The analysis indicate that social capital score mean of young people show no statistically significant difference in proportion to age groups $(p>0.05, t=-0.566)$; gender $(p>0.05, t=1.273)$; educational status $(\mathrm{p}>0.05, \mathrm{~F}=0.318)$; parental education status $(\mathrm{p}>0.05, \mathrm{t}=0.114)$; employment status $(\mathrm{p}>0.05, \mathrm{t}=-1.933)$ (Table 3$)$. 
As shown in Table 3, social capital shows a significant difference when evaluated according to the perceived income status $(\mathrm{p}<0,001, \mathrm{~F}=5,129)$. The Scheffe test results to determine which groups the difference occurred demonstrate that the score means of those with low $(71.82 \pm 8.47)$ income status are lower than those with high (77.20 \pm 8.25$)$ income status, and they are statistically significant.

Table 3. Social Capital Scores of Young People By Variables

\begin{tabular}{|c|c|c|c|c|}
\hline Variables & $\begin{array}{l}\text { Social capital } \\
\text { Avg. } \pm S . C .\end{array}$ & Difference & $t / D$ & s \\
\hline \multicolumn{5}{|l|}{ Age Groups } \\
\hline Between 18-22 (1) & $74.39 \pm 9.32$ & - & -0.566 & 0.572 \\
\hline Between 23-29 (2) & $74.85 \pm 8.81$ & & & \\
\hline \multicolumn{5}{|l|}{ Gender } \\
\hline Male (1) & $75.20 \pm 9.16$ & - & 1.273 & 0.203 \\
\hline Female (2) & $74.16 \pm 8.95$ & & & \\
\hline \multicolumn{5}{|l|}{ Educational Status } \\
\hline High school and below (1) & $73.90 \pm 8.99$ & - & 0.318 & 0.728 \\
\hline Undergraduate (2) & $74.78 \pm 9.09$ & & & \\
\hline Postgraduate (3) & $74.64 \pm 8.98$ & & & \\
\hline \multicolumn{5}{|l|}{ Parental Educational Status } \\
\hline High school and below (1) & $74.66 \pm 9.43$ & - & 0.114 & 0.909 \\
\hline Undergraduate and postgraduate (2) & $74.57 \pm 8.39$ & & & \\
\hline \multicolumn{5}{|l|}{ Employment Status } \\
\hline Employed (1) & $73.95 \pm 9.15$ & - & -1.933 & 0.050 \\
\hline Unemployed (2) & $75.53 \pm 8.86$ & & & \\
\hline \multicolumn{5}{|l|}{ Perceived Income Status } \\
\hline Low (1) & $71.82 \pm 8.47$ & & 5.129 & 0.060 \\
\hline Medium (2) & $74.65 \pm 9.15$ & (1)-(3) & & \\
\hline High (3) & $77.20 \pm 8.25$ & & & \\
\hline
\end{tabular}

The Pearson Correlation Analysis results to determine the direction and severity of the bilateral relationship between social capital and life satisfaction are included in Table 4. Accordingly, social capital level and life satisfaction $(\mathrm{r}=0.342)$ were found to be positively correlated at a level of $0.01(\mathrm{p}<0.01)($ Table 4$)$.

Table 4. Evaluation of the Relationship Between Social Capital and Life Satisfaction

\begin{tabular}{lll}
\hline & & Life Satisfaction \\
\hline Social Capital & $\mathrm{r}$ & 0.342 \\
& $\mathrm{~s}$ & $0.01^{* *}$ \\
\hline
\end{tabular}

${ }^{* *} p>0.01$ 


\section{Conclusion and Discussion}

In this study, the social capital score mean of young people was well above the average level. In a study conducted by Ardahan (2014b), including various age groups in Antalya province, it was found that the social capital score mean of individuals was above the medium level. In a study conducted by Uçar and Morsünbül (2018), including students dwelling in Aksaray province, social capital was found below. Herewith, it is evident that social capital levels may vary by different regions and opportunities in those regions. In this respect, it can be said that metropolitan cities such as Ankara and Antalya, which have many facilities, play an essential role in the increase of the social capital level of young people.

The life satisfaction score mean of young people is above medium level. Correlatively, it was found in the study conducted by Gülcan (2014), evaluating "the effect of optimism on happiness and life satisfaction in young adults," that the life satisfaction of young people was at a medium level. According to the results of the "Life Satisfaction Survey" conducted in the "Youth with Statistics 2019" study of Turkey Statistical Institute (TURKSTAT), the rate of young people who claim that they are happy is a little more than half of the total young population (56.7\%).

In parallel with the increase in education level, individuals find more ample opportunities in terms of professional relations and time as part of social participation. In general, most of the studies conducted on social capital consider education one of the most important social capital determinants (Günkör, C. and Özdemir, 2017). Nevertheless, contrary to this view, it was found in the present study that the social capital score mean of the young people did not show significant differences regarding their educational status. The social capital score mean of the young people evaluated by other socio-demographic variables does not show significant differences in age groups, gender, parental education status, and employment status. Undoubtedly, future studies examining the effect of sociodemographic variables on social capital will be of great importance in terms of making more definite judgments on this issue and determining the actions to be taken in this direction.

The social capital score mean of young people was analyzed as per the perceived income, and significant differences were found. Considering 
the differences, the social capital score mean of those with low income is lower than those with high-income status and is significant. Giving countenance to this result, Brodrecht (2012) states that the increasing exclusion and poverty of low-income people limits the social resources of these disadvantaged groups and their economic resources. Furthermore, lack of social capital, mostly stemming from poverty factors such as money, rendezvous, necessary tools and applications, organizational ability, communication skills, may have weakened the ability to take standard action regarding social problems (Gündüz and Sağlam, 2020).

The youth period is an essential process of an individual's life, in which the perpetual behaviors of an individual are shaped. In this process, one of the most critical factors determining young people's life satisfaction is their social capital. A positive relationship was found between social capital and life satisfaction in the studies conducted abroad on social capital (McPherson, et al. 2014; Bjørnskov, 2008; Klein, 2013). A similar linear relationship between social capital and life satisfaction was demonstrated in a study conducted in the USA by Calcagnini and Perugini (2019). In the study conducted by Alghamdi and Plunkett (2021), it was found that students' social capital has a strong positive effect, especially on life satisfaction. Geraee, Eslami, and Soltani (2019) remarked that social capital's most vital precursor is life satisfaction. In our country, studies evaluating the relationship between social capital and life satisfaction in young people are limited. A linear relationship between social capital perception and life satisfaction was found by Ardahan (2014a) in his studies evaluating the relationship between social capital and life satisfaction from the point of undergraduates. In the present study, it was found that young people's life satisfaction increases in line with the social capital level.

The present study shows that young people with high social capital scores also have high life satisfaction. In line with these results, it is deemed necessary to develop course contents and methods further, starting from the early education age, to improve young people's social capital. The most crucial factor in developing social capital will be the education given to young people with a perspective open to self-improvement. According to the "Youth with Statistics 2019" survey of the Turkish Statistical Institute (TURKSTAT), the most up-to-date data source, the young population constitutes 15.6 percent of Turkey's population. Considering that, it 
is of great importance to increase such studies. The study is limited to the young population dwelling in Ankara; thus, the study should be reconducted with individuals of all age groups and in different regions, and in the light of the studies, relationships with many other variables missing in the literature should be evaluated with a more inclusive sample.

In consideration of the future comprehensive studies, evaluations to be made regarding the determination of the social needs of young people and determination and development of social capital types emerging in line with the needs, the protection of the existing social capital, and the creation and use of capital in cases where it is not available, is of great importance. To understand the self-realization motivation of young people, examining social capital in all its dimensions will provide policymakers, educators, and families with an essential perspective in terms of presenting the problems and solutions that young people experience. This and similar studies have an important place in understanding young people and producing policies in this direction.

Solving the social problems of societies, increasing the civil and political participation of young people, who are the most dynamic element of society, and popularizing democratic values will increase the opportunities for social capital accumulation in society. Regulations and practices that encourage young people's competition affect the development of their social capital positively. Shepherding the society; academics, politicians, bureaucrats, and the media can play an essential role in including more elements that will ensure the development of social capital accumulation in future policies by emphasizing the positive impact of social capital accumulation on the development of society more. In this way, young people's social capital level will increase in parallel with their life satisfaction, as outlined in the present study. It is indeed beyond doubt that; young people, as happy individuals who are our future, will increase social welfare.

\section{References}

Alghamdi, A. A. and Plunkett, M. (2021). The perceived impact of social networking sites and apps on the social capital of Saudi postgraduate students: A case study. Future Internet, 13(1), 20. 
Ardahan, F. (2012). Sosyal Sermaye Ölçeği geçerlilik, güvenirlilik çalışması. International Journal of Human Sciences, 9(2), 773-789.

Ardahan, F. (2014a). Sosyal sermaye, yaşam doyumu ve akademik başarı ilişkisi: BESYO örneği. International Journal of Human Sciences, 11(1), 12121226. doi: 10.14687/ijhs.v11i1.2754.

Ardahan, F. (2014b). Bireylerin sosyal sermaye profili: Antalya örneği. Akademik Sosyal Araştırmalar Dergisi, 2(8), 38-56.

Arrow, K. J. (2000). Observations on social capital, social capital: A multifaceted perspective. Ed.: Partha Dasgupta, İsmail Serageldin, Washington: The World Bank.

Bichler, S. and Nitzan, J. (2020). The capital as power aproach: An invited-thenrejected interview with Shimshon Bichler and Jonathan Nitzan (No. 2020/02). Working Papers on Capital as Power.

Bjørnskov C. (2008). Social capital and happiness in the United States. Applied Research in Quality of Life, 3, 43-62.

Bourdieu, P. (1986). The forms of capital in handbook of theory and research for the sociology of education. J. Richardson (ed.). New York : Greenwood, p.241-258.

Bourdieu, P. and Passeron J.C. (1977). Reproduction in education, society and culture. London: Sage.

Bulut N. (2016). Okul psikolojik danışmanlarının yaşam doyumu, stresle başaçıkma stratejileri ve olumsuz otomatik düşünceleri arasındaki ilişkiler. Türk Psikolojik Danışma ve Rehberlik Dergisi, 3(27),1-13.

Calcagnini, G. and Perugini, F. (2019). Social capital and well-being in the Italian provinces. Socio-Economic Planning Sciences, 68, 100668.

Chou, K. Y. (2003). Modelling the impact of network social capital on business and technological innovations, Research Paper, No:890, The University of Melbourne, http://www.economics.unimelb. edu.au/research/workingpapers/ wop03/890.pdf, (Erişim tarihi: 30.01.2021).

Coleman, J. S. (1988). Social capital in the creation of human capital. American Journal of Sociology, 94, 95-120.

Coleman, J. S. (1990). Foundation of social theory. Cambridge Mass: Harvard University.

Diener E., Suh E.M., Lucas R.E. and Smith H.L. (1999). Subjective well-being: Three decades of progress. Psychological bulletin, 125(2), 276.

Diener, E., Emmons, R. A., Laresen, R. J. and Griffin, S. (1985). The satisfaction with life scale. Journal of Personality Assessment, 49, 71-75. 
Erkuş, A. (2013). Bilimsel araştırma süreci. Ankara: Seçkin Yayıncılık.

Field, J. (2006). Sosyal sermaye. (Bahar Bilgen and Bayram Şen, Çev.) İstanbul: İstanbul Bilgi Üniversitesi. (Orijinal eserin yayın tarihi 2003).

Fukuyama, F. (1998). Güven. (Ahmet Buğdaycı, Çev.) Ankara: Türkiye İş Bankası Kültür Yayınları. (Orijinal eserin yayın tarihi 1995).

Watson W. and Steven, D. P. (2012). Social capital and organizational commitment. Journal of Business and Psychology, 16, 537-552.

Geraee N., Eslami A.A. and Soltani R. (2019). The relationship between family social capital, social media use and life satisfaction in adolescents. $\mathrm{He}$ alth Promotion Perspectives, 9(4), 307-313.

Gündüz, D. U. and Sağlam, E. (2020). Öteki mekânlarda sosyal sorunlar: bir literatür taraması. OPUS Uluslararası Toplum Araştırmaları Dergisi, 16(29), 2142-2178.

Günkör, C. and Özdemir, M. Ç. (2017). Sosyal sermaye ve eğitim ilişkisi. Türk Ĕ̆itim Bilimleri Dergisi, 15(1), 70-90.

Harper, R. (2002). The measurement of Social Capital in the United Kingdom, Office for National Statistic. http://www.oecd.org/dataoecd/22/52/2382339.pdf

Keleş, Ş., Keskin, A. and Ertek, N. (2018). Kırsal alanda sosyal sermayenin yaşam memnuniyeti üzerine etkisi. Tarım ve Doğa Dergisi, 21, 123.

Khan, Z., Hussain, M., Shahbaz, M., Yang, S. and Jiao, Z. (2020). Natural resource abundance, technological innovation, and human capital nexus with financial development: A case study of China. Resources Policy, 65, 101585.

Kıral, G., Mavruk, C. and Kiral, E. (2019). Fiziksel yetersizlik, umutsuzluk, parasal problem ve sosyal sermayenin yalnızlık hissi üzerine etkisi. OPUS Uluslararası Toplum Araştırmaları Dergisi, 14(20), 239-261.

Klein, C. (2013). Social capital or social cohesion: What matters for subjective wellbeing? Social Indicators Research, 110(3), 891-911.

Koçak, T.C. (2011). Toplumsal ilişkilerin sosyal sermaye değeri (topluluk duygusu ve sosyal sermaye üzerine bir araştırma). Doktora tezi. Selçuk Üniversitesi, Sosyal Bilimler Enstitüsü, Sosyoloji Anabilimdalı, Konya.

Köker, S. (1991). Normal ve sorunlu ergenlerin yaşam doyumu düzeyinin karşılaştırılması. (Yüksek Lisans tezi). Ankara Üniversitesi, Sosyal Bilimler Enstitüsü, Ankara. 
Leary, M. R., Tambor, E. S., Terdal, S. K. and Downs, D. L. (1995). Self-esteem as an interpersonal monitor: The sociometer hypothesis. Journal of Personality and Social Psychology, 68, 518-530.

Lin, N. (1999). Social networks and status attainment. Annual Review of Socio$\log y, 25,467-487$.

McPherson K., Kerr S., McGee E., Morgan A., Cheater F., McLean J. and Egan J. (2014). The association between social capital and mental health and behavioural problems in children and adolescents: An integrative systematic review. BMC Psychology, 2(1),7.

Murat, S. ve Şahin, L. (2011a). Gençlerin istihdamı/işsizliği bakımından türk eğitim sisteminin değerlendirilmesi. Çalışma ve Toplum Dergisi, 30, 93135.

Onyx, J. and Bullen, P. (2000). Measuring social capital in five communities. Journal of Applied Behavioral Science, 36(1), 23-42.

Özuğurlu, A. (2006). Sosyal sermaye: kamunun trajedisi ya da emeğin sömürgeleştirilmesinde yeni bir eşik. Akdeniz Üniversitesi İ̈BF Dergisi, 12, 188-213.

Putnam, R. D. (2000). Bowling alone: The collapse and revival american community. New York: Simon and Schuster.

Tel, F. D. and Sarı, T. (2016). Üniversite öğrencilerinde öz duyarlılık ve yaşam doyumu. Abant İzet Baysal Üniversitesi Ĕ̆itim Fakültesi Dergisi, 16(1), 292-304.

Uçar, M. E. and Morsünbül, Ü. (2018). Yatay dikey bireycilik/toplulukçuluk sosyal sermaye arasındaki ilişkiler. OPUS Uluslararası Toplum Araştırmaları Dergisi, 9(16), 794-822.

Woolcock, M. (2000). Social capital in theory and practise: Where do we stand?, Paper Prepared For The 21st Annual Conference on Economic Issues, Department of Economics, Middlebury College, Middlebury, Vermont, 7-9 April 2000, http://www.worldbank.org/poverty/scapital/index.htm,(Erişim tarihi:27.02.2021).

\section{Citiation İnformation}

Öztürk, M. S. ve Yilmaz, N. (2021). An examination of social capital in young people according to life satisfaction and somesocio-demographic factors. OPUS-Journal of International Society Studies, 18(44), 7520-7538. DOI: 10.26466/opus.904662. 